\title{
Exploring the relationship between direct and indirect spillovers from FDI in Argentina
}

Citation for published version (APA):

Narula, R., \& Marin, A. (2005). Exploring the relationship between direct and indirect spillovers from FDI in Argentina. MERIT, Maastricht Economic Research Institute on Innovation and Technology. MERITInfonomics Research Memorandum Series No. 024 https://doi.org/10.26481/umamer.2005024

Document status and date:

Published: 01/01/2005

DOI:

10.26481/umamer.2005024

Document Version:

Publisher's PDF, also known as Version of record

\section{Please check the document version of this publication:}

- A submitted manuscript is the version of the article upon submission and before peer-review. There can be important differences between the submitted version and the official published version of record.

People interested in the research are advised to contact the author for the final version of the publication, or visit the DOI to the publisher's website.

- The final author version and the galley proof are versions of the publication after peer review.

- The final published version features the final layout of the paper including the volume, issue and page numbers.

Link to publication

\footnotetext{
General rights rights.

- You may freely distribute the URL identifying the publication in the public portal. please follow below link for the End User Agreement:

www.umlib.nl/taverne-license

Take down policy

If you believe that this document breaches copyright please contact us at:

repository@maastrichtuniversity.nl

providing details and we will investigate your claim.
}

Copyright and moral rights for the publications made accessible in the public portal are retained by the authors and/or other copyright owners and it is a condition of accessing publications that users recognise and abide by the legal requirements associated with these

- Users may download and print one copy of any publication from the public portal for the purpose of private study or research.

- You may not further distribute the material or use it for any profit-making activity or commercial gain

If the publication is distributed under the terms of Article $25 \mathrm{fa}$ of the Dutch Copyright Act, indicated by the "Taverne" license above, 


\section{MERIT-Infonomics Research Memorandum series}

\section{Exploring the relationship between direct and}

indirect spillovers from FDI in Argentina

\section{Rajneesh Narula \& Anabel Marin}

\section{$2005-024$}

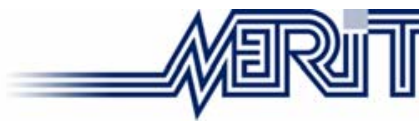

MERIT - Maastricht Economic Research Institute on Innovation and Technology

PO Box 616

6200 MD Maastricht

The Netherlands

T: +31433883875

F: +31 433884905

http://www.merit.unimaas.nl

e-mail:secr-merit@merit.unimaas.nl

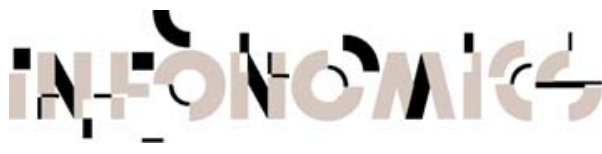

International Institute of Infonomics

c/o Maastricht University PO Box 616

6200 MD Maastricht

The Netherlands

T: +31433883875

F: +31453884905

http://www.infonomics.nl

e-mail: secr@infonomics.nl 


\title{
Exploring the relationship between direct and indirect spillovers from FDI in
}

\section{Argentina}

\author{
Rajneesh Narula and Anabel Marin
}

Version August 14 ${ }^{\text {th }}, 2005$

\begin{abstract}
This paper seeks to examine the paradox that despite the growing role of FDI in most economies and growth in their share of employment, exports and innovation ('direct spillovers'), evidence of technological spillovers to domestic firms in the host economy ('indirect spillovers') is sparse. Given the explicit dependence of the development strategies of developing countries on FDI after liberalization, it is important for us to ask: Why are these indirect spillovers not occurring? The evidence examined here shows that for the case of Argentina, there are direct spillovers in the form of human capital development and employment. However, there is no evidence of significant positive indirect spillovers to non-affiliated firms in Argentina. Part of this paradox may be explained by the fact that MNEs have acquired the most technologically competitive of their domestic rivals, and crowded out others. However, we postulate that there are a variety of other economic reasons why FDI may prove to be less useful as a driver of industrial development than has previously been argued. The extent to which direct spillovers result in indirect spillovers is intermediated by a number of factors, associated with the MNE and the nature of its assets and the organization of its global operations; the influence of increased cross-border competition on the distribution, concentration and competence level of affiliates and domestic firms, and the nature and extent of the absorptive capacity of the domestic sector.
\end{abstract}




\title{
Exploring the relationship between direct and indirect spillovers from FDI in
}

\section{Argentina}

\author{
Rajneesh Narula and Anabel Marin
}

\section{Introduction}

It is generally accepted that attracting and embedding inward foreign direct investment (FDI) has important development effects because FDI may represent an important source of technological spillovers. Although not the only means available, spillovers from FDI are regarded as one of the most practical and efficient means by which industrial development and upgrading can be promoted (Dunning and Narula 2004). Indeed, FDI is actively being promoted by the Washington consensus as a panacea for economic development. Structural adjustment programmes prominently integrate macroeconomic stabilization policies alongside policies to promote increased inward FDI. As a consequence, inward FDI is now actively sought by most developing countries. However, while the potential for MNE-related spillovers is clear, the nature, level and extent of the benefits vary considerably, and the outcomes from a FDI-assisted industrial policy are not always positive (Lall and Narula 2004).

One of the most significant aspects of potentially positive spillovers are those associated with and through human capital development. Human capital development has been recognised as one of the main drivers of economic growth (e.g., Romer, 1990). MNEs can influence human capital development in the host country through direct means, as MNEs contribute to the generation of employment in the host country, which is to say they can increase the employment level quantitatively.

Despite the importance given to MNEs they do not, however, account for a major force in employment; they are estimated to represent less than $2 \%$ of total employment in the developing world. Thus, the contribution to domestic employment from FDI does not seem very impressive, from a quantitative point of view at least. However, MNEs tend to be concentrated in the more 'dynamic' sectors of the economy (Harrison, 1999). Thus, even though they play a relatively small role in most economies in terms of level of total employment, MNEs often play a disproportionately large role in two very different types 
of industrial sectors. On the one hand, they tend to concentrate their activities in the more competitive or dynamic sectors typified by high growth rates and the use of new and emerging technologies (e.g., electronics, communication equipment, and industrial machinery). On the other, MNEs tend to dominate in mature sectors where economies of scale, branding and advertising determine market share (e.g., petroleum products, chemicals, automobiles, food and beverages and consumer goods). In such sectors, while the technology underlying these industries may be diffused and codified, capital limitations and marketing capabilities have meant that just a few MNEs maintain a large share of the global market.

MNEs can also cause direct increases in the quality of the domestic workforce, by providing formal and informal training, as well as through the process of learning-bydoing transferring their firm-specific technological knowledge to their domestic employees.

In addition to these direct effects, MNEs can furthermore affect human capital through indirect means, again both quantitatively and qualitatively. This occurs on a quantitative level if domestic suppliers and customers increase their own employment as a consequence of the increased economic activity of MNEs in the host economy. It occurs on a qualitative level if, firstly, MNE affiliates provide training and technical assistance to domestic suppliers and clients and secondly, if domestic firms gain access to more productive pools of potential employees who have been trained by MNE affiliates in newer and more productive technologies. According to the literature, the qualitative indirect effects are one of the more efficient sources of FDI-related technology spillovers since new technologies introduced by MNEs can move across foreign and domestic firms through the physical movement of workers who have been exposed to the technology.

Despite the clear potential for various kinds of spillover effects, empirical studies have not indicated that widespread and significant spillover effects are common. Instead, much of the evidence is contradictory (Lipsey, 2002, Gorg and Strobl, 2001). As Smarzynska (2002) puts it, “The difficulties associated with disentangling different effects at play and data limitations have prevented researchers from providing conclusive evidence of positive externalities resulting from FDI".

In this paper, we intend to disentangle several of these effects to develop a 
preliminary understanding of why MNE spillovers remain somewhat ambiguous, particularly in developing countries, paying particular attention to human capital development. We will also examine new empirical evidence of direct and indirect effects of FDI in a host intermediate country, namely Argentina. We base this analysis on the Innovation Survey in Argentina.

The structure of the paper is as follows. Following this introduction, section 2 presents a literature review of FDI-related benefits, considering the theory and evidence on both direct and indirect effects. In section 3 we discuss some of the reasons why direct spillover effects do not translate into indirect technological spillovers in developing countries that have liberalised their economies. In section 4 we present the results of our estimations for Argentina. First we investigate direct effects from FDI on human capital development and other indicators of technological behaviour. Second, we discuss the results of our estimations of indirect effects from FDI. Finally, section 5 draws out some broader conclusions.

\section{LITERATURE REVIEW}

\subsection{Direct spillovers}

Direct human capital development is one of the main potential contributions of FDI insofar as human resources can play a crucial role not only in the dissemination of technological knowledge from MNEs to the domestic sector, but also in the dissemination of best practices and other organizational innovations which are more difficult to disseminate in other ways. These benefits are expected to arise through two means. First, there is expected to be a tangible increase in the employment levels of qualified workers in the host location. Second, there is expected to be an increase in the quality of the workers potentially available to work in other companies or to start their own companies in the same country. This arises through the (expected) provision of formal training and education to MNE workers or potential workers.

Trained workers expand the knowledge base of firms and can benefit them in number of ways. They can stimulate the implementation of superior technologies and innovation, and also improve the absorptive capabilities of firms, which help them to 
learn from other sources. These workers also, when they move to other firms, move specific knowledge learnt in the subsidiary, which may not be possible to obtain in any other way.

Despite the enormous importance of this potential contribution of FDI to human capital development in developing countries, there are few empirical studies on this topic. In the theoretical literature, Fosfuri et al (2001) have recently demonstrated the conditions under which direct and indirect effects on human capital development emerge in association with FDI. They show that MNEs train local workers only when they need to use superior technologies in the foreign subsidiary. Under these conditions, however, they argue that the MNEs pay a higher salary to local workers in order to prevent them from moving to a local competitor, thereby dissipating proprietary technology.

Glass and Saggi (2002) provide a formal representation of the movement of trained workers from MNEs to domestic firms as a channel for spillover effects. However, in the same way as Fosfuri et al (2001), they conclude that MNEs may pay a wage premium to prevent local firms from hiring their workers and gaining access to their superior knowledge. Thus, although there is a benefit from FDI due to the wage premium, the benefit of technology transfer to local firms is less probable. Moreover, they argue that if this benefit occurs at all it will happen in industrialised regions where MNEs do not have as substantial advantage over domestic firms.

Empirical work on this specific topic is even more scant and the evidence is far from conclusive. In relation to training effects, early studies from different countries seem to point all in the same direction. MNEs are important providers of training (ILO, 1981, Lindsey, 1986). This has been confirmed for the UK (see Sousa, 2001) as well as the Czech Republic (Djankov and Hoekman, 1999) and in Kenya (Gershenberg, 1987). Gershenberg (1987), however, also showed that a "much smaller proportion of all managers trained in MNEs firms move to the non-MNE sector than is true of managers employed for other kind of firms", which reduce the opportunities for indirect or spillover effects. The same was found recently in a study in Costa Rica (Ciarli and Giuliani 2005).

In a recent study by Gorg and Strobl (2004) based on firm level data for manufacturing firms in Ghana , firms whose entrepreneurs had worked for MNEs in the same industry were more productive than domestic firms whose entrepreneurs had not 
worked in the MNE sector. No such effect is found however, when the entrepreneur worked before in a MNE in a different industry. The authors suggest that at least some of the MNE's knowledge is specific to the industry, and cannot be transferred to others. Bloom (1992) also finds substantial technology transfer via movement of professionals from MNEs to the domestic sector in South Korea, and Pack identifies important movements of workers between the two sectors- foreign and domestic- in the electronic industry for Taiwan (Glass and Saggi, 2002).

\subsection{Indirect spillovers}

We now turn our attention to indirect effects. In many cases the indirect transfer of technological knowledge to domestic agents might occur through backward and forward linkages when MNEs provide training and technical assistance to their local suppliers, subcontractors and customers. MNE subsidiaries need to interact with domestic external economic agents (in particular, firms and non-firms) in order to carry out their normal operations in the country, and these interactions may disseminate skills and technological transfer to the rest of the host economy.

Local competitors might also benefit from subsidiaries' presence when subsidiaries demonstrate new technologies and new ways to use them, or when highly skilled staff, trained in the foreign firm, move to incumbent domestic plants taking with them knowledge acquired in the affiliates.

The effects from increased competition due to FDI are not so clear. Ideally, increased competition resulting from FDI might induce domestic technological improvements by contributing to the elimination of inefficient indigenous firms, encouraging the birth of new innovative firms and inducing local firms to react to the foreign threats by assimilating foreign technologies and mobilising resources. Caves (1974) and Chung (2001) argue that this should not be considered a spillover effect because it does not involve any flow of knowledge. In addition, as noted by Aitken and Harrison (1999), increased competition associated with foreign presence might also 
reduce the productivity of domestically owned firms if foreign firms draw demand from them and the domestic firms have to cut production and increase costs ${ }^{1}$.

Much of the evidence points to very limited indirect benefits from FDI. Earlier studies, mostly based on industry level data and cross sectional analysis, found positive results (e.g. Caves 1974 or Globerman, 1979). However, positive results from this type of research design can be explained by reasons other than the existence of technology spillovers from FDI. In particular, Aitken and Harrison (1999) have noted an important identification problem: MNEs tend to operate in relatively high-productivity sectors in the host economy. The relatively high incidence of FDI in an industry may induce the exit of less competitive domestic firms, thus raising the average productivity level of the industry because of the larger share of technologically superior foreign firms in its output $^{2}$, rather than by diffusing any productivity raising technology to domestic firms.

It is now generally accepted that cross sectional industry-level studies are unable to identify the relevant causality. Consequently, recent studies have exclusively used firmlevel designs, typically combined with the use of panel data analysis. This provides better tools to solve the causal identification problem ${ }^{3}$. The effect of these methodological changes has been quite striking. The generally positive results in the earlier generation of studies have largely disappeared, both for advanced industrial economies - e.g. Sweden (Braconier et al., 2001) or the USA (Chung, 2001), and also when they are transition or industrialising economies - see for example Haddad and Harrison, (1991 and 1993) on Morocco, Djankov and Hoekman (2000) on Czech Republic, Aitken and Harrison (1999) on Venezuela, and Konings, (1999) on Poland, Bulgaria and Romania.

The evidence would seem to suggest that direct spillovers in terms of employment, training and so forth are relatively unambiguous and are in general positive. On the other hand, FDI does not necessarily deliver the indirect benefits expected by industrialising

\footnotetext{
${ }^{1}$ Indeed there is no agreement about the relationship between FDI, competition and technical change in domestic firms. Conventional wisdom has mostly argued that FDI will introduce more competition in local market and therefore that local efficiency will be improved. However, some empirical works have found that FDI may increase concentration rather than competition, although it is also argued that sometimes concentration may promote innovation.

${ }^{2}$ Caves (1974) has denominated this effect, changes in the allocative efficiency.

${ }^{3}$ But it has not addressed the problem that, if the competitive pressure effects ('pseudo-spill-overs') are not partialled out, positive results might still be obtained in the absence of 'genuine' knowledge spillovers.
} 
countries. Many developing countries have explicitly built their industrial development strategies on the premise that FDI provides considerable, tangible indirect spillovers and externalities that accrue to domestic firms, it behoves us to ask why, and to explore the specific circumstances under which different type of effects arise. The next section will seek to provide a preliminary explanation for this paradox.

\section{Understanding why FDI does not always result in substantial indirect spillovers}

As discussed in the previous section, MNE benefits to the host economy in the form of indirect spillovers are not always positive or tangible. While there are often direct spillovers that derive from FDI activity, it is not always clear that these translate into indirect benefits to the host economy at large. Although some of the results are influenced by methodological and data-driven limitations, we postulate that there are a variety of economic reasons why FDI may prove to be less useful as a driver of industrial upgrading and development than has previously been argued. We argue in this section that the extent to which direct spillovers result in indirect spillovers is intermediated by a number of factors, associated mainly with, 1) the MNE and the nature of its assets and the organization of its global operations; 2) The influence of liberalization on the host country's economic structure; 3) the nature and extent of the absorptive capacity of the domestic sector.

These factors are themselves highly interdependent. It is important to acknowledge that MNEs are rarely interested in the explicit transfer of knowledge. Ceteris paribus, they prefer to use technologies that are suited (first and foremost) to their own needs, and the purposes for which they have made the investment. MNEs tailor their investment decisions to the existing market needs, and the relative quality of location advantages, especially skills and capabilities in which the domestic economy has a comparative advantage (Lall 2002: 17).

\subsection{The nature MNE firm-specific assets}


There are two points we wish to make: First, that while it is a reasonable assumption that MNEs are in possession of superior firm-specific assets, the assets that they bring to any given location are not always those which domestic firms necessarily seek to acquire- or even - are able to acquire. Keep in mind that the MNE's competitive advantages derive from two types of firm-specific assets: First there are those associated with technological assets in the traditional sense, such as machinery and equipment, and in the personnel who operate and maintain them. These are asset-specific ownership advantages, and it is these that the economics literature concentrate on as being the source and basis for spillovers (see e.g., Markusen 1998, Carr et al 2001). The second type of firm-specific assets are those associated with conducting transactions efficiently, that derive from being able to generate rent by virtue of superior use of intra-firm hierarchies, both within and across national borders. This group also include those that derive by virtue of the multinationality of the firms and can be termed 'advantages of common governance'. These are transaction-type firm-specific assets (see Dunning 1993, Cantwell and Narula 2001). MNEs can exist in the absence of technology type ownership advantages, generating rent simply from its superior knowledge of markets and hierarchies. Thus, MNEs may possess the same (or even 'inferior') technology-type assets relative to its domestic counterparts, yet still out-compete them. For instance, simply a privileged access to a market, access to suppliers and other parts of the MNE network. In such cases, indirect technological spillovers - in the conventional way they are understood and measured - will not occur. However, other types of spillovers might occur, and they will affect other dimensions rather than the technological ones in domestic firms.

Second, it is an unreasonable assumption that domestic firms will automatically benefit from MNE assets, either because the domestic firms do not have the capacity to do so, or because the assets are strongly firm-specific in nature as is the case with transaction-type ownership advantages. That is, such transaction-type firm-specific assets cannot be acquired easily since they are highly tacit, firm-specific and largely uncodified, and are acquired only gradually. This makes quantitatively measuring such spillovers incredibly difficult, and it should not be expected that such benefits will accrued in the short or medium term. 


\subsection{The motive of the FDI and the level of competence of MNE subsidiaries.}

The motive of an investment helps to determine (in conjunction with the hostcountry specific factors) the kind of MNE affiliate and therefore the potential for spillovers. It is generally acknowledged that there are four main motives for investment: to seek natural resources; to seek new markets; to restructure existing foreign production through rationalisation, and to seek strategically related created assets (Narula and Dunning 2000). These in turn can be broadly divided into two types. The first three represent motives which are primarily asset-exploiting in nature: that is, the investing company's primary purpose is to generate economic rent through the use of its existing firm-specific assets. The last is a case of asset-augmenting activity, whereby the firm wishes to acquire additional assets, which protect or augment their existing created assets in some way. In general, developing countries are unlikely to attract much assetaugmenting FDI. Developing countries have tended to receive FDI that is primarily resource-seeking, market-seeking or efficiency seeking, and the relative importance of each is a function of the stage of economic development which itself is a function of the quality of its absorptive capacity (Narula and Dunning 2000, Narula 2002). Least developed countries will tend to have a predominance of resource-seeking FDI, while in countries such as Argentina, which can be regarded as being in the catching-up stage, a majority of FDI might be directed towards market-seeking, while efficiency seeking investments would be the exception rather than the rule. Resource-seeking FDI would still be important, but of less significance than market-seeking FDI. As countries approach the frontier (e.g., NICs), efficiency seeking FDI will tend to dominate (Narula 2002).

Once the decision to enter a given market through FDI is taken, the kinds of activity and the level of competence of the subsidiary are co-determined by the nature of the location advantages of the host location. That is to say, while MNE internal factors such as their internationalization strategy, the role of the new location in their global portfolio of subsidiaries, and the motivation of their investment are pivotal in the structure of their investment, they are dependent on the available location-specific resources which can be 
used for that purpose. Indeed, the host country's location advantages play an important role in determining the level of embeddedness of the subsidiary (Benito et al 2003), and this is the primary determinant of the quality of the FDI. High competence subsidiaries require complementary assets that are non-generic in nature, and are often associated with agglomeration effects, clusters, and the presence of highly specialized skills. In other words, firms are constrained in their choice of location of high competence subsidiaries by resource availability. For instance, R\&D activities tend to be concentrated in a few locations because the appropriate specialized resources are associated with a few specific locations. MNE investments in high value-added activities (often associated with high competence levels) have the tendency to be 'sticky'. Such subsidiaries tend to be embedded with the local milieu in terms of linkages with suppliers, customers and domestic institutions. The linkages are both formal and informal, and will probably have taken years - if not decades - to create and sustain. As such, the embeddedness of firms is often (but not always) a function of how long the MNEs have been present, since firms tend to build incrementally. This has been observed to be the case in East Asia (See e.g., Rasiah 1994, 1995), but it is to be noted that firms build on location advantages that already exist in the host economy (Ritchie 2002), and increases in embeddedness are generally in response to improvements in the domestic technological and absorptive capacity.

The point here is that not all affiliates provide the same opportunity for spillovers (see Marin and Bell, 2005, and Bell and Marin, 2005). A sales office may have a high turnover, employ a large staff, but the indirect spillovers to other co-located firms will be smaller than, say, a manufacturing facility. Likewise, resource-seeking activities, can be capital intensive, employ many staff, but also provide fewer spillovers than say, a marketseeking type of FDI.

\subsection{The restructuring of MNE affiliates' after economic liberalisation}

Prior to economic liberalization, MNEs responded to investment opportunities primarily by establishing miniature replicas of their facilities at home, although the extent to which they were truncated varied considerably between countries. The extent of truncation was determined by a number of factors, but by far the most important 
determinant of truncation- and thereby the scope of activities and competence level of the subsidiary - were associated with market size, and capacity and capability of domestic industry (Dunning and Narula 2004). There is thus a hierarchy of the quality of FDI activity in the developing countries which reflects the stage of industrial development. At the 'bottom', least developed countries without a domestic sector and with low demand have been host to the most truncated subsidiaries, often to the point of being singleactivity subsidiaries. Activities were primarily in sales and marketing, and natural resource extraction. The most advanced economies with domestic technological capacity have hosted the least truncated subsidiaries, often with R\&D departments.

Developing countries have not necessarily benefitted from an increase in the quality of FDI that they receive because of liberalization. Although there has been some investment in new affiliates resulting in new (greenfield) subsidiaries that did not exist previously, there has also been a downgrading of subsidiaries. MNEs may divest their operations in response to better opportunities elsewhere in the, or reduce the intensity of operations by lowering the level of competence and/or scope of their subsidiary, and shifting from truncated replicas to single activity affiliates. There may also be a redistribution effect. That is, sectors that were dominated by domestic capital were transferred to foreign ownership. This has also, in many cases, led to a downgrading of activities from truncated replica to single activity affiliates, and a reduction in employment to reduce duplication between locations within the MNE.

MNEs have taken advantage of liberalization to rationalise production capacity in fewer locations to exploit economies of scale, especially where local consumption patterns are not radically different to justify local capacity and where transportation costs are not prohibitive. This has meant that some miniature replicas have been downgraded to sales and marketing affiliates, which can be expected to have fewer opportunities for spillovers. It is ironic that the countries that receive the kinds of FDI that has the highest potential benefits vis-à-vis industrial development are those that already have a highly developed domestic absorptive capacity (Narula and Marin 2003). Domestic capacity in the same industry - whether in the form of knowledge infrastructure or efficient domestic industrial sector - is a primary determinant of high competence foreign affiliates, and therefore tangible and significant indirect spillovers. 
As firms increasingly use global production networks, MNEs locate their activities to take advantage of the most strategic fit to their global operations, and this often means that they make no significant efforts to create linkages with the domestic economy. In a perfectly liberalised world, MNEs have no incentive to encourage the development of domestic firms to meet their needs since they can do so using either imports or FDI. In an extreme case, there may actually be no indirect spillovers from FDI, because MNEs will prefer to locate production in a regionally optimal location and simply import all their inputs. Where this has happened, the market share of MNEs has risen, while at the same time, their contribution to the host economy (such as direct and indirect employment) has actually fallen.

\subsection{Absorptive capacity as a determinant of linkages}

Several studies have pointed to the fact that indirect benefits generally only accrue to domestic firms in the same industry as the MNE (vertical spillovers), and rarely are there significant inter-industry, horizontal spillovers. For indirect spillovers of either kind, however, two pre-conditions must be met. First a domestic sector must exist, and second, that they possess the capacity to usefully internalise the knowledge being made available by the MNE (indirectly or directly). In other words, the domestic industry must possess the absorptive capacity to efficiently exploit spillovers. The presence of a viable domestic sector is not a condition that is always met, since MNEs (and their wellestablished global supply chains) often tend to crowd-out existing domestic firms (Agosin and Mayer 2000), or in other cases, acquire the more competent domestic firms. This is particularly true in the the catching-up countries where foreign capital has substituted for domestic capital, taking over domestic firms through M\&A that possessed technological resources but were unable to produce as efficiently with MNEs after liberalization.

It is essential when trying to appreciate the importance of absorptive capability to take a systems view of an economy, and by doing so acknowledge that all the economic firm and non-firm actors within an industry are indivisibly interlinked. If the institutions and organisations are absent or underdeveloped, economic actors within the system will be unable to absorb and efficiently internalise knowledge. Absorptive capacity includes 
the ability to internalise knowledge created by others and modifying it to fit their own specific applications, processes and routines (Narula 2004). It is worth noting that absorptive capacity is a subset of technological capability, which in addition to absorptive capability includes the ability to generate new technologies through non-imitative means. This does not imply that absorption is purely about imitation. Firms cannot absorb outside knowledge unless they invest in their own $R \& D$, because it can be highly specific to the originating firm, since it has a partly tacit nature. The extent to which a firm is able to exploit external sources of knowledge thus depends on its absorptive capacity which is assumed to be a function of its R\&D efforts, and the degree to which outside knowledge corresponds to the firm's needs as well as the general complexity of the knowledge. An important component of absorptive capacity is the availability of an appropriate supply of human capital, which in turn is not always specific to firms, but associated with the capabilities of the non-firm sector. Non-firms determine the knowledge infrastructure that supplements and supports firm-specific innovation. They account for a certain portion of the stock of knowledge at the national level which may be regarded as 'general knowledge' in the sense that it has characteristics of a public good, and is potentially available to all firms that seek to internalise it for rent generation.

Thus, even where technological assets are made available through spillovers from inward FDI the domestic sector may not be in a position to internalise these assets. Borenzstein et al (1998) and Xu (2000) have both shown that FDI has a positive impact on economic growth only in those developing countries that have attained a certain minimum level of absorptive capacity. Knowledge accumulation is much more rapid once the initial threshold level of absorptive capacity exists. Simply put, technology absorption is easier, once they have 'learned-to-learn’ (Criscuolo and Narula 2002). The cost of imitation increases as the follower closes the gap with the leader and the number of technologies potentially available for imitation reduces.

\section{The Case of Argentina}

Our analysis is supported by detailed firm level data from two Innovation Surveys in Argentina. The first Survey covers the period 1992-1996, the second, the period 19982001. Argentina is a particularly interesting example for this study given that (as a result 
of rapid FDI growth in the 1990s) its manufacturing industry has become heavily dependent on foreign firms: $49.6 \%$ of the largest industrial firms in 2002 were MNEs. When joint ventures are included, this figure rises to 77\%. Moreover, Argentina has had a historical dependence on MNEs, and is regarded to have achieved a threshold level of absorptive capabilities. The Innovation Survey in Argentina, following the broad framework of the Oslo Manual, covers numerous aspects of the economic and technological behaviour of 1533 firms (283 of which are MNEs). The survey sample is representative of the universe of industrial firms in the country, and includes $50 \%$ of the total industrial firms, which account for $53 \%$ of total sales, $50 \%$ of total employment, and 61\% of total exports (The Annex in Narula and Marin (2003) describes the firms and information covered by the dataset). Table 1 gives the industrial distribution of the different types of affiliates, utilising the Ferraz classification. Ferraz allocates into five broad categories all the 4-digit manufacturing industries (SIC codes). The taxonomy is similar in principle to the OECD and other classifications of industries in terms of their technology-intensity. However, recognising that the same industry codes may incorporate very different technological characteristics in different economic contexts, it was developed to differentiate industries in the Latin American context. The categories and example industries are shown in the Annex .

\section{***Table 1 about here ${ }^{* * *}$}

The case of Argentina illustrates to some extent the general phenomena discussed earlier. The increased role of MNEs in certain sectors is in part a result of aggressive liberalisation of FDI regimes and privatisation programmes. Indeed, the greatest change has been the reduction in state ownership and the subsequent privatisation of assets. As table 2 shows, between 1996 and 2001, foreign firms substantially increased their participation in a number of sectors in terms of sales. Sectors where the share of MNE sales increased included communications equipment, from 49\% of total sales in 1996 to around $94 \%$ in 2001, and motor vehicles, from $54 \%$ to $96 \%$ of sales in 2001 . FDI also dominates sectors such as petroleum with around $90 \%$ of total sales, chemicals with around $66 \%$ of sales, and fabricated metal products, with around $59 \%$ of total sales It is 
worth noting, however, that in a number of sectors (e.g., textiles, precision, medical and optical equipment, rubber and plastics, electronics) the share of FDI in total sales as well as in employment declined substantially over the same period. It is interesting to note that in several sectors, employment either decreased more substantially than sales of MNEs. In certain sectors such as food, paper, lumber and wood products, leather products, the share of MNE sales increased or stayed constant while employment declined, indicating the possible increase of intra-firm exports substituting for local production. In yet other sectors increases in share of sales were shadowed by a smaller proportional increase in employment share, suggesting the use of economies of scale or the use of global supply chains of MNEs.

\section{***Table 2 about here***}

\section{$\underline{4.1 \text { Examining direct effects of FDI in Argentina }}$}

In this sub-section the evidence for the Argentinean case is used to evaluate the direct contribution of FDI to domestic human capital development. Our data allows us to identify an interesting sub-group within the group of MNEs affiliates, firms that were acquired by MNEs between 1996 and 1998. Thus, by comparing changes in human development indicators for firms that were acquired by MNEs, relative to other domestic firms and subsidiaries, we are able to identify the effects that emerge exclusively as a consequence of FDI.

Table 3 summarises some general features of these three groups of firms, specifically average size, market share, investment intensity and export intensity. Some interesting issues can be appreciated by looking at these indicators. First, that acquired firms were rather atypical for their group before they changed hands. They were three times bigger than the average domestic firm, and had a slightly higher market share and propensity to export. The intensity of investment was the same as the other domestic firms. Second, both acquired and MNE subsidiaries -but especially the acquired onesreduced size in the second period, and increased substantially their market share and export intensity, compared to domestic firms. Nonetheless, as expected, subsidiaries 
perform better on all indicators, as compared with domestic firms. They are much bigger, possess a higher market share, and invest and export a higher proportion of their total sales. It is interesting to note that the export intensity of the acquired firms increased substantially between 1992 and 1998 .

\section{***Table 3 about here***}

Table 4, 5 and 6 summarise the results of the analysis on the impact of FDI on human development. The human development indicators evaluated are the following: use of professional workers (engineers and other professionals), an index of skills (professional/non-professional workers), expenditures on training activities, and intensity of professionals workers dedicated to R\&D activities. In addition, table 7 provides some evidence on the evolution of R\&D intensity.

Measurements in Tables from 4 to 7 are reported in absolute levels (means) and as intensities. Thus, for example, a value of 11 in column 1 in table 4 indicates that domestic firms employ 11 professional workers, in average, and that this group of workers represents $5 \%$ of the total force for the average domestic firm.

\section{***Table 4 about here ${ }^{* * *}$}

Data from table 4 reveals several issues. First, acquired firms appear again as atypical when compared with the other domestic firms before the acquisition, which confirms that foreign firms tended to acquire domestic firms which on average had a similar skills level to their own, as well as the firms with the highest absorptive capacity. Second, subsidiaries hire a larger number of professional workers, both in absolute levels and as a proportion of their workforce. In 1992 for instance, subsidiaries employed 89 professionals on average whilst domestic firms only employed 11. These differences increased substantially over time. By 2001, the typical subsidiary increased the average number of professionals to 111 , acquired firms declined to 56, and domestic firms remained at the same level.

Although on average acquired firms decreased the level of professional workers, at the same time they increased the intensity of skilled workers. This would again suggest 
that the firms acquired were among the most dynamic and with the greatest absorptive capacity, but that after acquisition, considerable rationalisation was undertaken by the MNE to eliminate duplication and achieve economies of scale.

Similar results are suggested when we examine expenditures on training (Table 5). Subsidiaries spent on average 8 times as much as domestic firms on training in 1998, and by 2001 this had increased to a factor of 10 . On a per worker basis, which allows us to adjust for the relative differences in the size of establishment, domestic firms showed a decline in the expenditures on training per worker, while subsidiaries and acquired firms increased these expenditures between 1998 and 2001. Subsidiaries had higher levels of training expenditures, both in absolute levels and in intensity, and they most increased the absolute level of expenditure. However, this is not fully reflected in the evolution of intensities because subsidiaries increased employment substantially as well.

\section{***Table 5 about here ${ }^{* * *}$}

Over the period 1992 to 2001, MNE affiliates spent around 30 or $40 \%$ more than domestic firms on R\&D. As table 6 shows, on average MNE subsidiaries had 7 R\&D employees compared to domestic firms which averaged less than 2 in 1998, although when adjusted for size, this represented an identical level of R\&D intensity in both 1998 and 2001. It is worthy of note that in both periods acquired firms had a higher R\&D intensity as well as a larger average R\&D staff than both domestic firms and subsidiaries in both periods. This might suggest that not only did MNEs target the most technologyintensive domestic firms for acquisition, but that they continued to maintain the level of competence of these newly acquired subsidiaries. Despite a large overall reduction in employment post-acquisition (table 3), acquired firms did not reduce the level R\&D activities, such that acquired firms had a R\&D intensity in employment of $3.5 \%$ compared with $2.4 \%$ for both domestic firms and subsidiaries in 2001. In effect, after they were acquired by foreign capital, this group of firms utilised professionals in $R \& D$ five times more than domestic firms. This would imply that the acquired firms were probably recognised as centres of excellence for innovation within their respective MNE networks. 


\section{***Table 6 about here***}

As discussed in section two, the main potential contribution of MNEs to host countries derives from their possession of superior knowledge. One of the best indicators of technology-type ownership advantages of a firm is its R\&D intensity. Table 7 describes changes in $R \& D$ intensities based on a ratio of $R \& D$ expenditures to sales. This confirms the evidence in table 6 . Subsidiaries seem to have, at least on average, some knowledge superiority to domestic firms., a difference that although substantial, is less important than the one identified in other type of indicators as training, or skills.

\section{***Table 7 about here***}

In summary, it can be concluded that MNE subsidiaries seem to possess superior knowledge resources as compared to domestic firms and they dedicated a relatively larger share of resources to human capital development, at least when compared with similar domestic firms. Both types of subsidiaries hired more professionals than domestic firms of the same size, possessed a more skilled labour force overall, and spent more on training than similar domestic firms. They also dedicated more resources to R\&D, professionals and investments, and in general the analysis of the evolution of these indicators indicates a trend in which these differences have become bigger not smaller. Finally, it is interesting to note that as resources have moved from domestic to foreign capital, there have been improvements in most of the human development indicators: skills, training expenditures and the proportion of workers in creative tasks, and also in $\mathrm{R} \& \mathrm{D}$. However, improvements in intensities are also a result of reduction in employment after acquisition, as a result of rationalisation of post M\&A operations. 


\section{$\underline{4.2 \text { Indirect effects on domestic firms }}$}

The evidence reviewed above indicates that there are clear human capital-related direct benefits from MNE activity in Argentina. This section examines whether these benefits result in indirect effects on the productivity and the skill levels of domestic firms.

Indirect effects are usually evaluated empirically by analysing the level or change in productivity of domestic firms that are in some way related with MNE affiliates. This empirical model have been considerably extended and refined since the studies pioneered by Caves (1974) and Globerman (1978). However, the basic approach has remained fundamentally similar. Measures of FDI participation or MNEs presence are related with measures of productivity growth in domestic firms, and when the association is positive, FDI is claimed to generate technology externalities. The analysis usually models the effects within the context of production functions. FDI is treated as an additional "input" explaining changes in the productivity of domestic firms that enjoy some point of economic contact with foreign firms. Thus, a significant coefficient for FDI is understood as evidence consistent with externalities. The typical formulation conventionally assumes three things.

1) That the level of productivity achieved by firms depends on the level of the pool of general knowledge accessible to it and not only on its own "research" efforts;

2) That the output differences that can not be attributed to the accumulation of any input (conventional input) -the Solow residual- can be visualised as technological progress;

3) That FDI -similar to R\&D- augments directly the domestically available stock of knowledge in its economic space.

On the basis of these assumptions, it is argued that, (accounting for other factors) the rate of productivity growth (or difference) of domestic firms increases when FDI increases, FDI must be “moving” domestic plants towards technological improvements.

The ideal way to evaluate these effects would require identification of domestic competitors and suppliers. However, due to data limitations about linkages between the 
two groups, we seek to evaluate indirect effect through two means. First, we estimate indirect effects by following common practice by analysing productivity improvements of domestic firms localised in the same 5-digit sectors as the subsidiaries ${ }^{4}$. Second, we go beyond this common methodology by examining FDI indirect effects on human capital by modelling a function of skills of domestic firms, which is augmented with indicators of FDI participation by industry. Skills are modelled as a function of the size of the firms and other indicators of knowledge capital and performance, and as a function of FDI participation in the industry, in the same period and with one and two time lags. Thus, the coefficient of FDI in this equation should capture two types of effects from FDI. On the one hand, the effects of an increased competitive pressure, since domestic firms might increase their skills intensity in order to compete with an increased participation of MNEs in their industries. On the other, it should capture the effects of movement of qualified workers between sectors as long as workers moved within the same 5-digit industry.

\section{$\underline{\text { Spillovers from FDI using production functions }}$}

The results of the externalities or spillovers from FDI are expected to affect domestic firms' productivity growth. FDI is treated as an additional "input” explaining productivity growth, and the coefficient of the FDI regressor is taken as evidence consistent with spillovers from FDI to the domestic sector. Variations of the following basic equation (equation 1') were used to investigate these effects:

$$
\Delta \ln Y_{i j}=\lambda \Delta \ln \text { Input }_{i}+\delta \Delta F D I_{j}+\varphi F \text { It }_{t-1}+\eta Z_{i j}+T+I+\varepsilon_{i}\left(1^{\prime}\right)
$$

In equation (1') the subscripts $\mathrm{i}$ and $\mathrm{j}$ denote plant and industry, $\Delta$ represents changes in the variables between $1992 / 1996,1996 / 1998$ and $1998 / 2001$, and $\lambda, \delta$, $\varphi$, and $\eta$ the parameters to be estimated. Y denotes added value at plant level, Input, its use of normal inputs, FDI is a measure of changes in FDI participation at industry level during the period analysed and lagged a period, denoted by subscripts $\mathrm{j}$ and $\mathrm{t}-1$, respectively. $\mathrm{Z}$ is

\footnotetext{
${ }^{4}$ Due to the lack of data we were not able to test for the possible presence of regional or inter-sectoral spillovers.
} 
a set of plant and industry level control variables. T and I are dummies for time and industries respectively.

For Input, we use total employment $(L)$ and the ratio of investment to added value $(I / Y)$.

FDIpart is the share of total employment in the 5-digit industry $j$ that is accounted for by all employment in foreign owned firms in the industry. ${ }^{5}$ We use an indicator based on employment rather than capital because labour turnover is likely to be a particularly important channel for spillover effects.

$G$ is a categorical dummy variable that distinguishes independent domestic firms from those that are part of a domestic conglomerate.

$I$ is a dummy variable distinguishing the 22 two-digit industries.

$Z$ includes a set of additional variables that may affect TFP' growth in domestic firms:

(a) $\Delta K C^{d}=$ change in knowledge capital, as reflected in $\mathrm{R} \& \mathrm{D}$ expenditures plus changes in the expenditure on new equipment specifically concerned with product or process innovation ${ }^{6}$

(b) $\Delta$ Skills $^{d}=$ change in the professional/non professional ratio (professionals include engineers and other professionals in production, administration and $\mathrm{R} \& \mathrm{D})$

5 This indicator was constructed on the basis of the information provided by the $50 \%$ sample survey because the data about FDI penetration at the 5-digit level for the whole economy does not exist. However, the Survey sample included all of the 500 largest industrial firms in Argentina. Since MNE subsidiaries in manufacturing industries in Argentina are typically large, almost all of them are probably included in the sample of 283 subsidiaries.

${ }^{6}$ R\&D expenditure is not a good indicator of the technological efforts of firms in developing countries in augmenting their knowledge capital, since such efforts are generally not formalised as explicit R\&D activities. We therefore include expenditures on equipment for product or process innovation as an additional indicator of these efforts. 
(c) $\Delta$ Comp $^{d}=$ changes in competition.

We expect that the increases in $K C$ and Skills will positively affect changes in total factor productivity of domestic firms through their effects on their knowledge capital (Griliches 1991). Their inclusion therefore reduces the possibility of bias due to nonincluded variables that change across domestic firms and over time.

Variables reflecting changes in competition are also introduced. As discussed earlier, FDI might also affect the level of competition in local markets, and through this channel, domestic firms' survival, behaviour and performance. To control for this effect, following Sjoholm (1997), Chung (2001), and Haskel et al (2002) we introduce in the regression two measures of potential competition: 1 ) changes in import penetration at the 5-digit industry level, and 2) changes in industry concentration measured by the changes in the Herfindahl index. We expect that - to the extent that these indices reflect changes in the levels of competition- changes in allocative and technical efficiency produced by an increased FDI should be captured by the index. Additionally, these variables should also capture changes in other unobservable variables that affect competition and that might have disciplined the domestic industry to become more efficient. Improvements in the efficiency of domestic industry are particularly relevant, as Argentina undertook significant market reforms during the period in question.

The expanded equation is as follows:

$$
\begin{aligned}
& \Delta \ln Y^{d}{ }_{i}=\alpha_{1} \Delta \ln L^{d}{ }_{i}+\alpha_{2} \frac{I_{i}}{Y_{i}}+\alpha_{3} \Delta \text { FDIpart }_{j}+\alpha_{4} \text { FDIpart }_{t-1}+\alpha 5 \Delta \text { Skills }_{i}+\alpha_{6} \Delta K_{i} \\
& +\alpha_{7} \Delta \text { Concen }_{j}+\alpha_{8} \Delta \operatorname{Im} \text { pen }_{j}+G_{i}{ }^{d}+I_{j}+\varepsilon_{i}
\end{aligned}
$$

\section{Where:}

$$
\begin{array}{ll}
\Delta \ln Y_{i} & =\text { The log change in value added } \\
\Delta \ln L_{i} & =\text { The log change in total employment } \\
I / L_{i} & =\text { The ratio of total investment to total output } 1992 \\
\Delta \text { FDIpart } & =\text { The change in FDI participation by industry }
\end{array}
$$




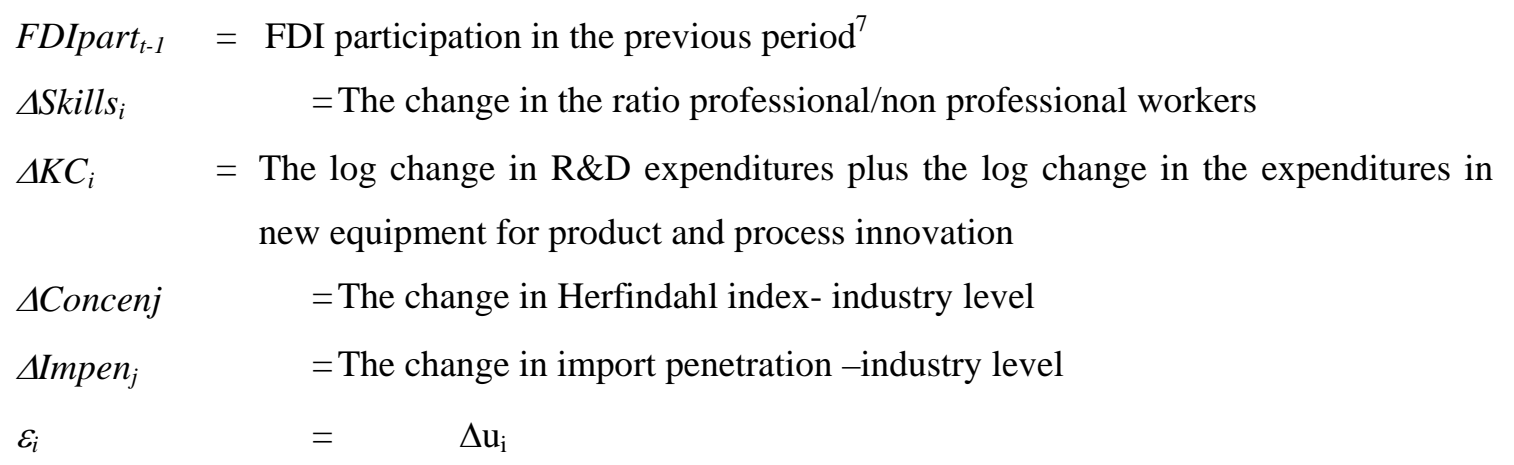

By using a plant level specification and modelling in first differences we control for fixed differences in productivity levels across industries, which might affect the level of foreign investment. In this way, we address the identification problem observed by Aitken and Harrison (1999) who have shown that in industry level cross section studies a positive result might reflect the fact that foreign firms are attracted to the more productive industries rather than a spillover effect ${ }^{8}$.

In addition, this specification and the inclusion of industry and year dummies correct for the omission of unobservable variables that might undermine the relationship between FDI and productivity growth of domestic firms. By observing changes over the time we remove plant-specific and industry and region fixed effects such as differences in the long-term strategy of the domestic firms, the regional infrastructure and differential technological opportunity of the industries.

\section{$\underline{\text { Skills spillovers from FDI }}$}

In order to evaluate the contribution of FDI to skill intensity of domestic firms we use a function of skills augmented with FDI participation by industry.

$$
\text { Skillsdf }_{i j}=\lambda \ln L_{i}+\alpha \ln K C_{i}+\delta \Delta F D I_{j}+\varphi \text { FDIt }_{t-1}+\rho \Delta \text { Concent }_{j}+T+I+\varepsilon_{i}
$$

\footnotetext{
${ }^{7}$ The previous period for 2001 is 1998, for 1998 is 1996 and for 1996 is 1992.

${ }^{8}$ We cannot completely rule out the possibility of spurious correlation if there are industry characteristics that change over the time and affect FDI localisation.
} 
We define skills intensity of domestic firms as the proportion of professionals to total workers per firms.

The basic function is intended to capture the effects of traditional determinants of skills as size, other investments in knowledge capital and the industry. Thus, the coefficient of FDI will capture the differential effect of an increased FDI participation in the industry of the domestic firms on the use of professional workers.

\section{$\underline{4.3 \text { Results }}$}

Table 8 and 9 show the results for the two different specifications used in order to investigate the effects of FDI on domestic firms. Table 8 reports the results of the productivity spillovers estimation Table 9 the results for skills spillover estimation. The coefficient for $\triangle \mathrm{FDIj}$ and $\mathrm{FDI}_{\mathrm{lag}}$ measures FDI indirect effects or spillovers. Thus, if the technology superiority of foreign firms spreads at industry level to domestic firms the coefficient of $\Delta$ FDIj and $\mathrm{FDI}_{\text {lag }}$ in table 8 should be positive. In the same way, if the superior use and development of human resources by subsidiaries spreads to domestic firms the coefficient for $\Delta \mathrm{FDIj}$ and $\mathrm{FDI}_{\text {lag }}$ in table 9 should be positive.

\section{***Table 8 and 9 about here ${ }^{* * *}$}

As can be seen in table 8, the added value of the firms in Argentina increases with changes in the employment of domestic firms, their knowledge capital, skills, market share and the import penetration at the industry level. However, changes in FDI participation at industry level do not seem to contribute to productivity improvements of the firms in the same industry: the coefficient for changes in FDI and FDI participation in the previous period are not significant.

In line with previous studies that have used panel data, we find no evidence of technological spillovers (or dynamic externalities) from FDI in Argentina between 1992 and 2001. Benefits of foreign firms' activities in the Argentinean economy are not reflected in domestic firms' value added growth, even when these activities have a high potential for technological spillovers. What are more surprising are the results in table 9, 
which demonstrate that an increased FDI participation in the same industry in a previous period is negatively associated with the skill intensity of the domestic firms.

\section{Discussion and conclusions.}

This paper has sought to examine the paradox that despite the growing role of FDI in most economies, evidence of technological spillovers to domestic firms in the host economy is sparse. Given the explicit dependence of the industrial development strategies of developing countries on FDI as a source of capital and technology after economic liberalization, it is important for us to ask: Why are these indirect spillovers not occurring? Indeed, as the evidence examined here has shown for the case of Argentina, there are direct spillovers in the form of human capital development and employment. However, there is no evidence of significant or positive indirect spillovers to nonaffiliated firms in Argentina.

There are several explanations for the lack of indirect spillovers to the domestic sector:

1. Increased FDI has had a negative competition effect. This is a result of two trends. First, conventional 'crowding out' has occurred: as MNEs increase competitive pressure on the domestic sector, domestic firms that have been unable to face this pressure choose to de-skill the labour force and move to cheaper niches in the market. Second, MNEs have acquired the most technologically competitive domestic firms. Thus, these firms can be regarded as also exiting, as ownership has been transferred from domestic to foreign.

2. there is limited real movement of workers between the MNE sector and the domestic sector in the host country, due in part to the higher salaries paid by MNEs subsidiaries in order to keep their qualified workers and prevent dissemination of their superior knowledge (Fosfuri et al 2001).

3. Spillovers may be occurring, but primarily between MNE affiliates and the domestic firms that they have acquired. As these firms were amongst the most technologically competitive with the highest absorptive capacity prior to acquisition, they would be in the best position to benefit from spillovers. However, as these acquired firms are now considered as MNE affiliates as well, 
while there may be an increased amount of intra-MNE linkages and spillovers, this would not show up in our analysis. Our data show that after acquisition, considerable rationalisation was undertaken by the MNE to eliminate duplication and achieve economies of scale.

4. As a considerable share of the MNE investment is in traditional sectors and commodities (table 2), it may be the case that the kinds of ownership advantages that MNE subsidiaries possess are transaction-type advantages and those associated with the economies of common governance. These assets are highly intangible, and often non-replicable since they are a function of the MNE's global production network and specific to large internationally dispersed and rationalised organisations. In other words, there is little evidence to suggest that superior technological assets explain their superior performance (Narula and Marin 2003). Where spillovers do occur, these may take decades to filter through to the domestic sector. Furthermore, as we have discussed in section 3, the motive of investment and the structure of the MNEs global configuration influences the extent to which subsidiaries are embedded, and the quality of spillovers. The fact that FDI activities do not demonstrate significant spillovers to the economy at large indicates that not all FDI provides the same opportunities for spillovers and linkages. For instance, resource-exploiting investments (say, in mining) seek to provide unprocessed raw materials (a relatively low value adding activity) which act as inputs to other affiliates that may be located elsewhere. Resource-seeking FDI may employ a large workforce and be capital intensive, but the potential for spillovers to domestic firms may be small.

Clearly, further research is needed to examine these effects on an industry-level basis. Our earlier study (Narula and Marin 2003) showed that in traditional, more 'mature' sectors foreign firms seem to have significantly influenced domestic productivity, and where foreign firms seem to out-perform domestic firms significantly. In the so-called 'dynamic and new technologies' sectors which are typically regarded as providing the highest potential for spillovers, domestic firms tend to outperform foreign affiliates in most measures of technological and absorptive capabilities. Indeed, some of the evidence 
reviewed here suggests that some of the $M \& A$ activity may have been of a strategic asset augmenting nature, whereby there is a reverse-technology transfer effect (see Criscuolo et al 2005 for a discussion). The fact that on average the acquired firms continue to have a higher R\&D intensity than domestic firms, as well as MNE subsidiaries in general, indicates that these new subsidiaries are probably seen as R\&D centres of excellence within the MNE hierarchy into which they are now embedded.

Our results confirm the opinion expressed by Mortimore (2000) that although Latin American countries have succeeded in attracting a large quantity of FDI, it has thus far ignored the issue of quality of FDI. At the same time, our analysis also points to a common oversimplification made by researchers in the field: That MNEs tend to possess technological assets superior to domestic firms. If FDI is intended to promote domestic industrial development, this calls for more careful screening mechanisms.

The bigger issue that our analysis raises is that a more sceptical approach needs to be taken of the Washington consensus and its simplistic view that FDI is a sine qua non for economic development. Market forces cannot substitute for the role of governments in developing and promoting a proactive industrial policy. MNEs and FDI may well lead to an increase in productivity and exports, but they do not necessarily result in increased competitiveness of the domestic sector or increased industrial capacity, which ultimately determines economic growth in the long run (Lall and Narula 2004).

To be sure, upgrading of technological capabilities of domestic firms can no longer be pursued in quite the same way in a globalising world. International competition is a given, and there can be no return to the infant industry model. Nonetheless, market forces cannot substitute for the role of governments in developing and promoting a proactive industrial policy. Firms necessarily take a shorter term, profit maximising view because they are largely risk averse. FDI per se does not provide growth opportunities unless a domestic industrial sector exists which has the necessary technological capacity to profit from the externalities from MNE activity. This is well illustrated by the inability of many Asian countries which have relied on a passive FDI-dependent strategy to upgrade their industrial development. FDI, domestic capabilities and a domestic sector need to be concatenated and properly phased if positive results are to be achieved. 


\section{References}

Agosin, M. and Mayer, R. (2000) 'Foreign investment in developing countries: does it crowd in domestic investment?' UNCTAD Discussion Papers No. 146.

Aitken, B. and Harrison, A. (1999) 'Do domestic firms benefit from direct foreign investment? Evidence from Venezuela', American Economic Review, 89(3): 60518.

Bell, M. and Marin, A. (2004), 'Where Do Foreign Direct Investment-Related Technology Spillovers Come From in Emerging Economies? An Exploration in Argentina in the 1990s ', The European Journal of Development Research, Autumn, 2004, vol. 16, no. 3, pp. 653-686(34).

Benito, G., Grogaard, B. and Narula, R. (2003) 'Environmental influences on MNE subsidiary roles: economic integration and the Nordic countries', Journal of International Business Studies, Vol.34, pp.443-56.

Blomstrom, M. and Sjoholm, F. (1999) 'Technology transfer and spillovers: Does local participation with multinationals matters?' European Economic Review, 43: 91523.

Borensztein, E., De Gregorio, J. and Lee, J.W. (1998) 'How does FDI affect economic growth', Journal of International Economics, 45: 115-35.

Braconier, H., Ekholm, K. and Midelfart Knarvik, K. (2001) 'Does FDI work as a channel for R\&D spillovers? Evidence based on Swedish data', IUI, The Research Institute of Industrial Economics, Working Paper No 553, Stockholm.

Cantwell, J. (1991) 'The theory of technological competence and its application to international production', in D. McFetridge (ed.), Foreign Investment, Technology and Economic Growth, Calgary: University of Calgary Press.

Cantwell, J. and Narula, R. (2001) 'The eclectic paradigm in the global economy', International Journal of the Economics of Business, Vol 8, pp 155-172,

Carr, D., Markusen, J. and Maskus, K. (2001) 'Estimating the knowledge-capital model of the multinational enterprise', American Economic Review 79(5):693-708.

Caves, R. (1974) 'Multinational firms, competition and productivity in host-country markets', Economica, 41(162).

Chung, W. (2001) 'Identifying technology transfer in foreign direct investment: influence of industry conditions and investing motives', Journal of International Business Studies, 32(2): 211-29.

Ciarli, T. and Giuliani, E. (2005) "Reformas estructurales y cambio estructural en Costa Rica. Dinámica industrial, heterogeneidad estructural y eslabonamientos: el papel de las inversiones extranjeras directas” in Cimoli, M. (ed.), El Reto de Accelerar el Crecimiento Economico en América Latina y el Caribe ,CEPAL, Santiago del Chile.

Correa, M. (1998) 'Argentina’s national innovation system', International Journal of Technology Management, 15(6/7): 721-57.

Criscuolo, P., Narula, R. and Verspagen, B. (2005), The relative importance of home and host innovation systems in the internationalisation of MNE R\&D: a patent citation analysis, Economics of Innovation and New Technologies, Vol 17, 417-433 
Djankov, S. and Hoekman, B. (2000) 'Foreign investment and productivity growth in Czech enterprises, World Bank Economic Review, 14 (1).

Dunning, J. (1993) Multinational Enterprises and the Global Economy, Wokingham: Addison-Wesley.

Dunning, J. H. and Narula, R. (2004) Multinational and Industrial Competitiveness: A New Agenda, Cheltenham: Edward Elgar

Fosfuri, A. and Motta, M. and Ronde, T. (2001) 'Foreign direct investment and spillovers through workers' mobility’, Journal of International Economics, Elsevier, vol. 53(1), pages 205-222.

Gershenberg, I. (1987), 'The Training and Spread of Managerial Know-how, a Comparative Analysis of Multinational and Other Firms in Kenya', World Development, Vol. 15, pp. 931-939.

Glass, A. and Saggi, K. (2002) 'Multinational Firms and Technology Transfer', Scandinavian Journal of Economics, Blackwell Publishing, vol. 104(4), pages 495-513.

Gorg H.and Strobl, E. (2001) 'Multinational Companies, Technology Spillovers and Plant Survival: Evidence for Irish Manufacturing', European Economy Group Working Papers 8, European Economy Group.

Gorg H. and Strobl, E. (2004) 'Foreign Direct Investment and Local Economic Development Beyond Productivity Spillovers’, GEP Research Papers, 04/11.

Griliches, Z. and Mairesse, J. (1995) 'Productions Functions: The search for identification”, Working Paper No. 5067.

Griliches, Z. (1991) 'The search for R\&D spillovers', NBER Working Paper No. 3768.

Haddad, M. and Harrison, A. (1991) 'Are there dynamic externalities from direct foreign investment? Evidence from Morocco', Industry and Energy Department Working Papers: Industry Series Paper No. 48.

Haddad, M. and Harrison, A. (1993) 'Are there positive spillovers from direct foreign investment? Evidence from panel data for Morocco', Journal of Development Economics, 42: 51-74.

Harrison, A. (1996) 'Determinants and effects of direct foreign investment in Cote d'Ivoire, Morocco and Venezuela', in Mark J. Roberts and James R. Tybout (ed) Industrial Evolution in Developing Countries, New York, Oxford University Press.

Haskel, J., Pereira, S. and Matthew, S. (2002) 'Does inward foreign direct investment boost the productivity of domestic firms?' National Bureau of Economic Research, Working Paper No. 8724.

International Labour Organisation (1981): 'Multinationals' Training Practices and Development', Geneva, ILO.

Javorcik, B. (2004) 'Does Foreign Direct Investment Increase the Productivity of Domestic Firms? In Search of Spillovers through Backward Linkages’, American Economic Review, American Economic Association, vol. 94(3), pages 605-627.

Kokko, A. (1994) 'Technology, market characteristics, and spillovers', Journal of Development Economics, 43: 279-93.

Konings, J. (1999) 'The effect of direct foreign investment on domestic firms: evidence from firm level panel data in emerging economies’, LICOS, Centre for Transition 
Economics, Economic Department, Catholic University of Leuven, Belgium and CEPR London.

Lall, S. (2002) 'Foreign direct investment, technology development \& competitiveness: issues and evidence', mimeo.

Lall, S. and Narula, R. (2004) FDI and its Role in Economic Development: Do We Need a New Agenda, European Journal of Development Research,2004, Vol 16

Lindsey, C. (1986), 'Transfer of technology to the ASEAN region by US transnational corporations', ASEAN Economic Bulletin, Vol. 3, pp. 225-247.

Lipsey, R. (2002) 'Home and host country effects of FDI', NBER Working Paper No. 9293.

Mansfield, E. and Romeo, A. (1980) 'Technology transfer to overseas subsidiaries by U.S. based firms', Quarterly Journal of Economics, 95(4).

Marin, A. and Bell, M. (2005), "Technology spillovers from foreign direct investment (FDI): the active role of MNC subsidiaries in Argentina in the 1990s", Journal of Development Studies, in SEWP 118, SPRU Working Papers: http://www.sussex.ac.uk/spru/1-6-1-2-1.html

Markusen, J. (1998) 'Multilateral rules on foreign direct investment: the developing countries stake', draft prepared for the World Bank.

Mortimore, M. (2000) 'Corporate strategies for FDI in the context of Latin America's new economic model’, World Development, 28(9): 1611-26.

Narula, R. (2002) 'Switching from import substitution to the 'New Economic Model' in Latin America: a case of not learning from Asia', MERIT Research Memorandum 2002-32.

Narula, R. (2003a) Globalisation and Technology: Interdependence, Innovation Systems and Industrial Policy, Cambridge: Polity Press.

Narula, R. (2003b) 'Multinational firms, regional integration and globalising markets: implications for developing countries', in R. Devlin and A. Estevadeordal (ed.), Trade and Regional Integration in the Development Agenda, Washington DC: Inter-American Development Bank.

Narula, R., (2004), 'Understanding Absorptive Capacities in an Innovation Systems Context: Consequences for Economic and Employment Growth', MERIT Research Memorandum 2004-003.

Narula, R. and Dunning, R. (2000) 'Industrial development, globalisation and multinational enterprises: new realities for developing countries', Oxford Development Studies, 28(2): 141-67.

Narula, R. and A. Marin, (2003), 'FDI Spillovers, Absorptive Capacities and Human Capital Development: Evidence from Argentina', MERIT Research Memorandum 2003-16.

Noorbaksh, F., Paloni, A. and Youssef, A. (2001) 'Human capital and FDI inflows to developing countries: new empirical evidence’, World Development, 29(9): 153161

Rasiah, R. (1994) 'Flexible production systems and local machine tool subcontracting: electronics component multinationals in Malaysia', Cambridge Journal of Economics, 18: 279-98.

Rasiah, R. (1995) Foreign Capital and Industrialization in Malaysia, London: Macmillan. 
Rasiah, R. (2002) 'Infrastructure and domestic patents in developing Asia', UNU/INTECH, Maastricht, mimeo.

Ritchie, B. (2002) 'Foreign direct investment and intellectual capital formation in South East Asia’, OECD Technical Papers No 194.

Romer, P. (1990) 'Endogenous Technological Change', Journal of Political Economy, University of Chicago Press, vol. 98(5), pages S71-102.

Sjoholm, F. (1997) 'Technology gap, competition and spillovers from direct foreign investment: evidence from establishment data', Stockholm School of Economics, Working Paper Series in Economic and Finance No. 211.

Smarzynska, B. (2002) 'Does Foreign Direct Investment Increase the Productivity of Domestic Firms' In Search of Spillovers through Backward Linkages', World Bank Working Papers 2923.

Sousa, N. (2001) 'Multinationals and Technology transfer through labour training', Mimeo, University of Nottingham (presented at a CEPR Workshop on Labour Market Effects of European Foreign Investments, Dublin, July 2001)

$\mathrm{Xu}$, B. (2000) 'Multinational enterprises, technology diffusion, and host country productivity growth', Journal of Development Economics, 62: 477-93. 


\section{ANNEX \\ DIFFERENTIATING INDUSTRIES USING THE FERRAZ CLASSIFICATION}

This classification of industries developed by Ferraz (1992), allocates all the 4-digit manufacturing industries (SIC codes) into five broad categories. The taxonomy is similar to the OECD and other classifications of industries in terms of their technology-intensity. However, recognising that the same industry codes may incorporate very different technological characteristics in different economic contexts, it was developed to differentiate industries in the particular context of Latin America. The categories and example industries are shown below.

Table 1 illustrates some of the industries included in each one of Ferraz categories, Table 2 shows all the 4-digit SIC codes included in each category.

Table A1: The Classification of Industries

\begin{tabular}{|c|c|c|}
\hline Ferraz Categories & Illustrative 4-digit SIC Industries & \\
\hline $\begin{array}{l}\text { INDUSTRIAL } \\
\text { COMMODITIES }\end{array}$ & $\begin{array}{l}\text { Dyeing and Finishing Textiles } \\
\text { Paperboard Containers } \\
\text { Industrial Inorganic Chemicals } \\
\text { Iron And Steel Foundries }\end{array}$ & $\begin{array}{l}\text { Less } \\
\text { Technology- } \\
\text { Intensive }\end{array}$ \\
\hline $\begin{array}{l}\text { AGRO-BASED } \\
\text { COMMODITIES }\end{array}$ & $\begin{array}{l}\text { Canned, and Preserved Fruits } \\
\text { Animal Fats And Oils } \\
\text { Grain Mill Products } \\
\text { Sugar }\end{array}$ & 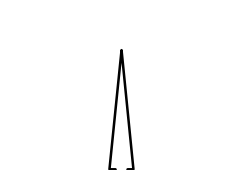 \\
\hline $\begin{array}{r}\text { TRADITIONAL } \\
\text { SECTORS }\end{array}$ & $\begin{array}{l}\text { Meat products } \\
\text { Bakery products } \\
\text { Apparel } \\
\text { Soap, Detergents and Cleaning Preparations }\end{array}$ & \\
\hline $\begin{array}{l}\text { DURABLE } \\
\text { GOODS }\end{array}$ & $\begin{array}{l}\text { Household Appliances } \\
\text { Watches } \\
\text { Motorcycles } \\
\text { Bicycles and Parts }\end{array}$ & \\
\hline $\begin{array}{l}\text { THE AUTOMOTIVE } \\
\text { SECTOR }\end{array}$ & $\begin{array}{l}\text { Motor Vehicles } \\
\text { Passenger Car Bodies } \\
\text { Motor Vehicle Equipment }\end{array}$ & V \\
\hline $\begin{array}{l}\text { DIFFUSERS OF } \\
\text { TECHNICAL } \\
\text { PROGRESS }\end{array}$ & $\begin{array}{l}\text { Pesticides and Agricultural Chemicals } \\
\text { Drugs } \\
\text { Farm Machines } \\
\text { Machines Tools } \\
\text { Communication Equipment } \\
\text { Electrical Industrial Apparatus } \\
\text { Aircraft and Space Vehicles }\end{array}$ & $\begin{array}{l}\text { More } \\
\text { Technology- } \\
\text { Intensive }\end{array}$ \\
\hline
\end{tabular}


When used to differentiate the industries of MNE subsidiaries, the underlying principle is: less knowledge-intensive firms in the more traditional and commodity industries towards the top of the table are likely to offer more limited spill-over potential than more knowledge-intensive firms in the industry categories towards the foot of the table.

Table A2 SIC codes distributed by Ferraz classification

\begin{tabular}{|c|c|c|}
\hline Ferraz Group & SIC code & \\
\hline Industrial Commodities & 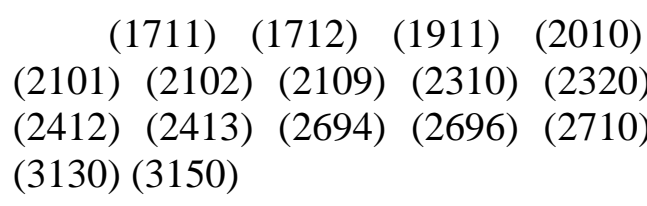 & $\begin{array}{l}(2021) \\
(2411) \\
(2720)\end{array}$ \\
\hline Agro-based commodities & $\begin{array}{llll}(1513) & (1514) \\
(1542) & (1531) & (1532)\end{array}$ & (1533) \\
\hline Traditional Goods & $\begin{array}{lllll} & (1511) & (1512) & (1520) & (1541) \\
(1544) & (1549) & (1551) & (1552) & (1553) \\
(1600) & (1721) & (1722) & (1723) & (1729) \\
(1810) & (1820) & (1912) & (1920) & (2022) \\
(2029) & (2211) & (2212) & (2213) & (2219) \\
(2222) & (2230) & (2424) & (2429) & (2430) \\
(2520) & (2610) & (2691) & (2692) & (2693) \\
(2699) & (2731) & (2732) & (2811) & (2812) \\
(2891) & (2893) & (2899) & (3140) & (3190) \\
(3691) & (3692) & (3693) & (3694) & (3699)\end{array}$ & $\begin{array}{l}(1543) \\
(1554) \\
(1730) \\
(2023) \\
(2221) \\
(2519) \\
(2695) \\
(2813) \\
(3610)\end{array}$ \\
\hline Durable Goods & $\begin{array}{cccc}(2930) & (3230) & (3320) & (3330) \\
(3591)(3592)(3599) & & \end{array}$ & $(3512)$ \\
\hline Automotive complex & (3410) (3420) (3430) & \\
\hline Dynamic and new technologies & 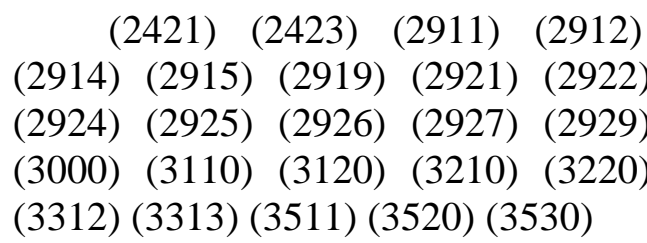 & $\begin{array}{l}(2913) \\
(2923) \\
(2930) \\
(3311)\end{array}$ \\
\hline
\end{tabular}


Table 1: Distribution of different types of affiliates according to the Ferraz classification of industries*

\begin{tabular}{lcccccc}
\hline Type of Firm & Commodities & $\begin{array}{c}\text { Food } \\
\text { processing } \\
\text { commodities }\end{array}$ & $\begin{array}{c}\text { Traditional } \\
\text { sectors }\end{array}$ & $\begin{array}{c}\text { Durable } \\
\text { goods }\end{array}$ & $\begin{array}{c}\text { Automotive } \\
\text { complex }\end{array}$ & $\begin{array}{c}\text { Diffuser of } \\
\text { technology }\end{array}$ \\
Domestic Firms & 107 & 33 & 391 & 25 & 24 & 98 \\
\% & 15.78 & 4.8 & 57.67 & 3.69 & 3.54 & 14.45 \\
Acquired Firms & 7 & 3 & 18 & 3 & 4 & 6 \\
\% & 17.07 & 7.3 & 44 & 7.32 & 9.76 & 1.46 \\
Subsidiaries all & 35 & 7 & 67 & 5 & 11 & 25 \\
\% & 23.3 & 4.67 & 44.67 & 3.33 & 8.46 & 16.67 \\
\hline Total & 149 & 43 & 476 & 33 & 39 & 129 \\
\% & 17.15 & 4.9 & 54.78 & 3.8 & 4.49 & 14.84 \\
\hline
\end{tabular}

Source: Argentinean Innovation Survey 1992-2001

*See Annex for explanation.

The cells indicate number of firms and participation by row, so the first cell for commodities and domestic firms indicates that in 1996 there were 107 domestic firms in commodities type of industries, which represented $15.78 \%$ of all domestic firms. 
Table 2: Foreign participation in the Argentinean industrial sector (1996 and

2001)*

\begin{tabular}{|c|c|c|c|c|c|c|}
\hline & \multicolumn{6}{|c|}{ FDI \% } \\
\hline & \multicolumn{3}{|c|}{1996} & \multicolumn{3}{|c|}{2001} \\
\hline & $\begin{array}{l}\text { Total } \\
\text { employment }\end{array}$ & Total sales & $\begin{array}{l}\text { Number of } \\
\text { firms }\end{array}$ & $\begin{array}{c}\text { Total } \\
\text { employment }\end{array}$ & Total sales & $\begin{array}{l}\text { Number of } \\
\text { firms }\end{array}$ \\
\hline Tobacco Industries & 100 & 100 & 100 & 62 & 95 & 22 \\
\hline Petroleum refining and related industries & 79 & 89 & 46 & 86 & 95 & 50 \\
\hline Electronics & 65 & 78 & 19 & 39 & 49 & 20 \\
\hline Stone clay glass and concrete products & 55 & 68 & 27 & 40 & 45 & 22 \\
\hline Chemicals and allied products & 57 & 66 & 44 & 59 & 68 & 41 \\
\hline Rubber and miscellaneous plastic products & 56 & 66 & 22 & 30 & 43 & 15 \\
\hline Primary metal industries & 62 & 62 & 22 & 67 & 78 & 17 \\
\hline Paper and allied products & 43 & 55 & 18 & 40 & 56 & 24 \\
\hline Motor vehicles and equipment & 54 & 54 & 34 & 83 & 96 & 42 \\
\hline Communication equipment & 50 & 49 & 29 & 90 & 94 & 50 \\
\hline Machinery and equipment & 46 & 46 & 15 & 25 & 36 & 21 \\
\hline Food and kindred products & 31 & 42 & 13 & 29 & 53 & 16 \\
\hline Precision, photographic medical optical & 22 & 38 & 20 & 4 & 10 & 9 \\
\hline Lumber and wood products except furniture & 25 & 29 & 7 & 10 & 33 & 10 \\
\hline Textile mill products & 28 & 28 & 8 & 9 & 13 & 10 \\
\hline Leather and leather products & 23 & 26 & 11 & 12 & 26 & 11 \\
\hline Miscellaneous manufacturing industries & 17 & 25 & 6 & 7 & 16 & 6 \\
\hline Fabricated metal products & 22 & 20 & 15 & 45 & 59 & 20 \\
\hline Printing publishing and allied products & 14 & 14 & 13 & 17 & 14 & 13 \\
\hline Transportation equipment & 1 & 1 & 5 & 28 & 36 & 5 \\
\hline Apparel and other finished products & 0 & 0 & 0 & 5 & 7 & 4 \\
\hline Computer and office equipment & 0 & 0 & 0 & 0 & 0 & 0 \\
\hline
\end{tabular}

Source: Argentinean Innovation Survey 1992-2001

* The cells indicate foreign participation in total employment, sales and number of firms per sector. The first row

indicates therefore that $100 \%$ of employees in tobacco industries in 1996 were employed by MNE affiliates, while

the same participation decreased to $62 \%$ in 2001. 
Table 3: Three different type of firms: Some general features

\begin{tabular}{|c|c|c|c|c|c|}
\hline Type of Firm & $\mathrm{N}^{1}$ & $\begin{array}{c}\text { Total } \\
\text { Employment }^{2} \\
\end{array}$ & Market Share & $\begin{array}{c}\text { Investments } \\
\text { Intensity } \\
\end{array}$ & Export Intensity \\
\hline YEAR & 1992 & & & & \\
\hline Domestic Firms & 678 & 169 & $3 \%$ & $11 \%$ & $8 \%$ \\
\hline Acquired Firms & 41 & 547 & $4 \%$ & $11 \%$ & $9 \%$ \\
\hline $\begin{array}{l}\text { Subsidiaries all } \\
\text { period }\end{array}$ & 150 & 584 & $6 \%$ & $10 \%$ & $13 \%$ \\
\hline Average all firms ${ }^{4}$ & 869 & 258 & $3 \%$ & $10 \%$ & $9 \%$ \\
\hline$\overline{\text { YEAR }}$ & 1998 & & & & \\
\hline Domestic Firms & 698 & 171 & $4 \%$ & $6 \%$ & $9 \%$ \\
\hline Acquired Firms & 41 & 361 & $5 \%$ & $13 \%$ & $16 \%$ \\
\hline $\begin{array}{l}\text { Subsidiaries all } \\
\text { period }\end{array}$ & 130 & 551 & $10 \%$ & $9 \%$ & $22 \%$ \\
\hline Average all firms ${ }^{4}$ & 869 & 236 & $5 \%$ & $7 \%$ & $12 \%$ \\
\hline
\end{tabular}

Source: Argentinean Innovation Survey 1992-2001

1 Number of firms

${ }^{2}$ Average number of employees per type of firm. So, the first cell indicates that in 1992 the typical domestic firms employed 169 workers

${ }^{3}$ Total investment /total sales: average per type of firm. So for domestic firms in 1992 the typical firm invest $11 \%$ of its total sales.

4 The row average contains the same indicator per type of firm without distinction according origin of capital.

Table 4: Evolution indicators of human capital development by type of firm: Professionals and skills intensity of labour.

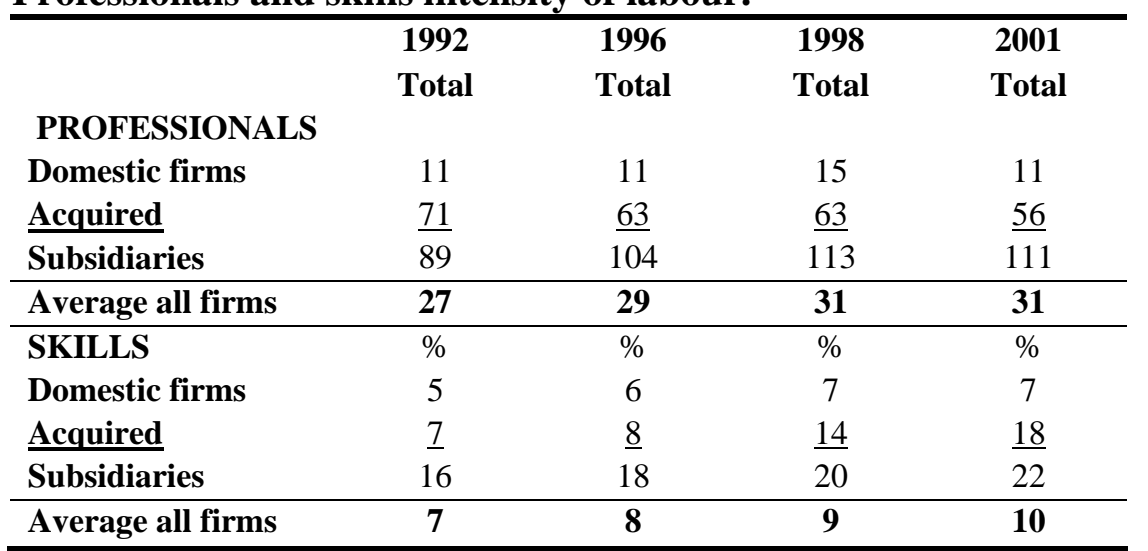

Source: Argentinean Innovation Survey 1992-2001

${ }^{1}$ Acquired firms are those that were domestic in the first period (1992-1996) and subsidiaries in the second (1998-2001).

${ }^{2}$ Professionals is the average total number of professionals per type of firm. So the table indicates that in 1992 domestic firms in average employed 11 professionals, while acquired firms employed 71 and subsidiaries 89.

${ }^{3}$ Skills is calculated as professionals over total employment. 
Table 5 Evolution intensity of expenditures in training activities*

\begin{tabular}{|c|c|c|c|c|}
\hline \multirow[b]{3}{*}{ Type of firm } & \multicolumn{4}{|c|}{ Training Expenditures } \\
\hline & \multicolumn{2}{|c|}{1998} & \multicolumn{2}{|c|}{2001} \\
\hline & $\begin{array}{c}\text { Total } \\
\text { Expenditure }^{1}\end{array}$ & Per Worker & $\begin{array}{c}\text { Total } \\
\text { Expenditures }\end{array}$ & Per Worker \\
\hline Domestic firms & 8064 & 39 & 7156 & 33.9 \\
\hline Acquired Firms & 39317 & 71 & 43689 & 98.2 \\
\hline Subsidiaries & 67313 & 160 & 80501 & 162.7 \\
\hline Total & 18414 & 59 & 19867 & 56.9 \\
\hline \multicolumn{5}{|c|}{ Source: Argentinean Innovation Survey 1992-2001 } \\
\hline \multicolumn{5}{|c|}{ * The values are expressed in Argentinean pesos. } \\
\hline
\end{tabular}

Table 6: Evolution indicators human resources in innovation tasks

\begin{tabular}{lcccc}
\hline Type of firm & \multicolumn{5}{c}{ \% Employees in R\&D } \\
\hline & $\begin{array}{c}\text { Total } \\
\text { number of } \\
\text { employees } \\
\text { in R\&D }\end{array}$ & $\begin{array}{c}\text { Intensity } \\
\%\end{array}$ & $\begin{array}{c}\text { Total } \\
\text { Number of } \\
\text { employees } \\
\text { in R\&D }\end{array}$ & $\begin{array}{c}\text { Intensit } \\
\text { y \% }\end{array}$ \\
\hline Domestic firms & 2 & 2.00 & 2 & 2.4 \\
Acquired Firms & 11 & 2.90 & 11 & 3.50 \\
Subsidiaries all & 7 & 2.00 & 8 & 2.40 \\
\hline $\begin{array}{l}\text { Average all } \\
\text { firms }\end{array}$ & $\mathbf{2 . 9}$ & $\mathbf{2 . 2 0 \%}$ & 3.4 & $\mathbf{2 . 4 0 \%}$ \\
\hline
\end{tabular}

Source: Argentinean Innovation Survey 1992-2001

${ }^{1}$ Average number of employees in R\&D 
Table 7: Evolution of intensity expenditures in R\&D

\begin{tabular}{|c|c|c|c|c|}
\hline Years & 1992 & 1996 & 1998 & 2001 \\
\hline Type of firm & \multicolumn{4}{|c|}{ Intensity of Expenditures In R\&D (\%)1 } \\
\hline Domestic Firms & 0.34 & 0.12 & 1.70 & 1.50 \\
\hline Acquired Firms & 1.08 & 0.15 & 2.00 & 1.60 \\
\hline Subsidiaries all & 0.47 & 0.15 & 2.90 & 2.00 \\
\hline Total & 0.39 & 0.12 & 1.90 & 1.60 \\
\hline
\end{tabular}

Source: Argentinean Innovation Survey 1992-2001

${ }^{1} \mathrm{R} \& \mathrm{D}$ total expenditures / sales

Table 8: Indirect effects: Productivity Spillovers towards domestic firms: Regressing added value at the plant level on inputs, knowledge capital (R\&D and skills) and the share of foreign firms at the industry level ${ }^{\text {a }}$

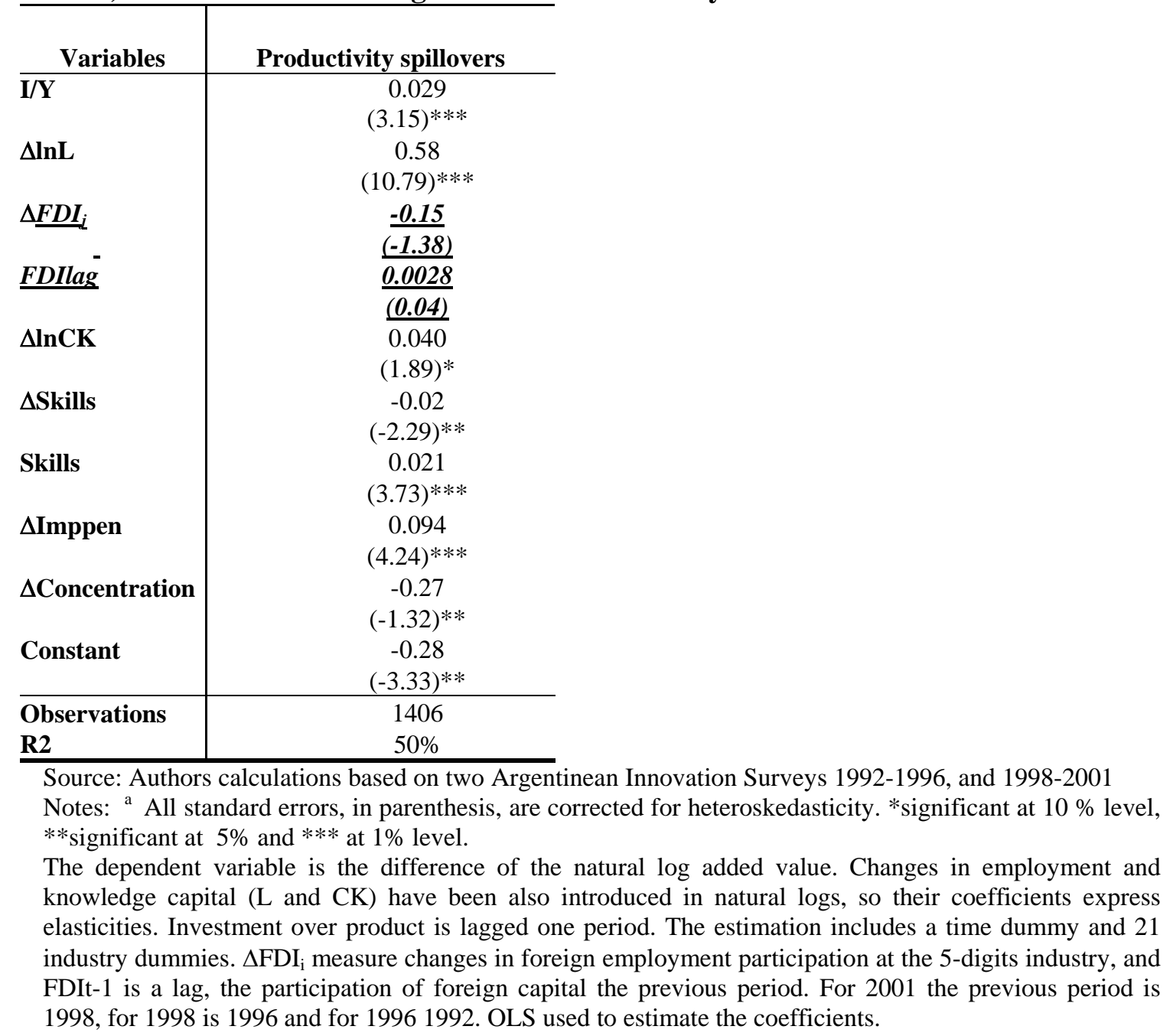


Table 9: Indirect effects: Skills spillovers towards domestic firms: Regressing skills intensity of domestic firms at the plant level on size, knowledge capital (R\&D and other investments in capital goods for innovations) and the share of foreign firms at industry level $^{\mathrm{a}}$

\begin{tabular}{l|c}
\hline \multicolumn{1}{c|}{ Variables } & Skills Spillovers \\
\hline$\Delta \operatorname{lnL}$ & -0.048 \\
$\Delta \underline{F D I}_{\mathbf{i}}$ & $(-9.35)^{* *}$ \\
FDIlag & $\underline{\mathbf{0 . 0 0 9}}$ \\
\hline LnCK & $\frac{\mathbf{( 0 . 6 3 )}}{\mathbf{- 0 . 0 8 8}}$ \\
& $\underline{(-2.42)^{* *}}$ \\
$\Delta \operatorname{lnCK}$ & 0.00053 \\
$\Delta$ Concentration & $(1.01)$ \\
& 0.0007 \\
Constant & $(0.19)$ \\
& 0.041 \\
Observations & $(1.81)^{* *}$ \\
\hline
\end{tabular}

Source: Authors calculations based on the Argentinean Innovation Survey 1992-1996

Notes: a All standard errors, in parenthesis, are corrected for heteroskedasticity. *significant at $10 \%$ level, $* *$ significant at $5 \%$ and $* * *$ at $1 \%$ level.

For this estimation we use fixed effects after rejecting OLS using the Breusch and Pagan (1980) Lagrange multiplier test for random effects and the possibility of a random effect model with the test of Hausman.

The dependent variable is the skills intensity of domestic firms, calculated as professionals over total employees. All the other variables are the same than in the previous estimation.

OLS is used to estimate the coefficients. 